\title{
1 \\ Labour Lines and Colonial Power
}

\author{
Victoria Stead and Jon Altman
}

\begin{abstract}
The Government's policy of buying stations and building large settlements - at considerable cost to the taxpayers-and then encouraging large numbers of natives to congregate on these places enjoying Government sustenance with a minimum of work has not helped the employment problem ... It would be easier, in our opinion, to 'blackbird' a boat load of Kanakas, than to pry loose a couple of native stockmen from some of these Government settlements.
\end{abstract}

Jim Martin, secretary of the Cattleman's Association, $1961 .^{1}$

In 1961, faced with low wages and poor living and working conditions, Aboriginal workers were leaving the northern Australian pastoral industry. Responding to the resultant labour shortage, the secretary of the Cattleman's Association of North Australia declared indignantly that the Aboriginal workers had not 'walked off but, rather, had been 'put off. In comments printed on the front page of the Northern Territory News, under the heading 'Natives "Lazy" - Cattlemen Say', he invoked long-running, racist stereotypes about the quality of Aboriginal labour, the alleged poor work ethic of Aboriginal people and the perceived immobility in which these moral failings were seen to be rooted. ${ }^{2}$ His racist comments were, of course, oblivious to the irony that what the labour

'Natives “Lazy”-Cattlemen Say', Northern Territory News, 18 April 1961, 1.

2 Konishi, 'Idle Men'. 
crisis in fact demonstrated was both the deep reliance of the industry on Aboriginal labour, and the capacity and willingness of Aboriginal people to enact agency through their mobility. Invoking the 'blackbirding' of Melanesian workers through the Pacific labour trade-a trade that had formally concluded six decades prior-the cattleman's comments likewise referenced (and exhibited) both the intertwined enactments of colonial power against both Indigenous and Pacific Islander people, and the reverberating presence of historical labour relations, discourses and identities.

The colonial complexes of race, labour and mobility evident in the cattleman's comments (and in the events that prompted them) reverberate throughout Australian colonial history and into the present. Today, increases of so-called 'low-skilled' and temporary labour migrations to Australia-including via dedicated seasonal labour schemes targeted to Pacific Islanders ${ }^{3}$ - occur alongside calls for Indigenous people to 'orbit ${ }^{\text {' }}$ from their remote communities in search of employment opportunities. These trends reflect the prevailing neoliberalism within contemporary Australia, as well as the effects of structural dynamics within the global agriculture and resource extractive industries. However, they are also, often, reflective of the rich cultures and histories of mobility, ${ }^{5}$ and the diverse 'worlding' practices of those who move, ${ }^{6}$ as well as of forces that compel movement. Drawing together historians, anthropologists, sociologists and geographers, this edited collection critically explores experiences of labour mobility (and immobility) by Indigenous peoples and Pacific Islanders, including Māori, within Australia. We seek to locate these new expressions of labour mobility within historical patterns of movement, including longer-term migrations, mobilities and diasporic settlements; in doing so, we also seek to comment on the contours and continuities of Australian coloniality in its diverse articulations.

3 Maclellan and Mares, 'Remittances and Labour Mobility in the Pacific'; Mares and Maclellan, 'Pacific Seasonal Workers for Australian Horticulture'; MacDermott and Opeskin, 'Regulating Pacific Seasonal Labour in Australia'.

4 Pearson, 'The Cape York Partnership Plan'. See also Neale, this volume; Pearson, 'Radical Hope: Education and Equality in Australia'; Pearson, Up from the Mission; cf. Altman, 'What Future for Remote Indigenous Australia?'.

5 Carey and Lydon, Indigenous Networks; Fijn et al., Indigenous Participation; Hau'ofa, 'Our Sea of Islands'; Taylor and Bell, Population Mobility and Indigenous Peoples.

6 Stead, 'Mobility and Emplacement'; Wilson and Connery, The Worlding Project. 
Contemporary experiences of labour mobility by both Pacific Islander and Indigenous peoples unfold within the context of long and troubled histories of Australian colonialism and postcolonialism. Thus, contemporary labour migrations of Pacific Islanders through the Seasonal Worker Programme (SWP)—oriented particularly to the agricultural and horticultural sectors - have dark historical echoes in the 'blackbirding' of South Sea Islanders to work on sugar plantations in New South Wales and Queensland in the late nineteenth and early twentieth centuries, as well as in wider patterns of labour, trade and colonisation across the region. ${ }^{7}$ The antecedents of contemporary Indigenous labour mobility, meanwhile, include forms of unwaged and exploitative labouring on government settlements, missions, pastoral stations and in the pearling industry, ${ }^{8}$ and also agentive and purposeful labour migrations, including by Indigenous intermediaries accompanying colonial explorations. ${ }^{9}$ Complex colonial histories and power relations inflect the contemporary encounters of both Pacific and Indigenous peoples with capitalist industry in Australia, as well as with the Australian state. They reverberate through past and present-day reckonings of class and race that posit certain types of work as undesirable for 'local' (white) labour, and through migration regimes that enact forms of precarious labour market access that are, for some, uncoupled from any possibility of citizenship.

The experiences of Indigenous and Pacific peoples speak to core, if diverse, expressions of Australian coloniality. These include the ongoing power relations and intercultural dynamics of settler colonialism, and also the kinds of racially structured hierarchies and North-South inequalities that Latin American and other postcolonial scholars have theorised as 'global coloniality' ${ }^{10}$ and that inform and inflect the ongoing making of 'Australia' and its regional positioning. Aníbal Quijano offers the idea of the 'coloniality of power' as a means of identifying the pervasive reverberations of colonialism through the present. ${ }^{11}$ Approached in this way, coloniality speaks to a system within which race, in its intersections with gender and other hierarchies, underpins foundational hierarchies that perpetuate unjust divisions of labour and that sustain the subordination of some for the benefit of others. As an analytical frame, the notion of

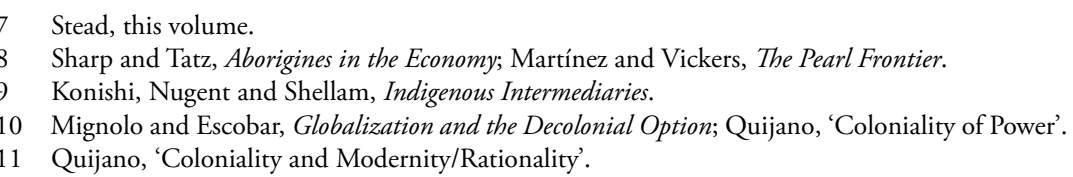


coloniality provides a productive basis for comparisons between different expressions of colonial power (e.g. settler and non-settler colonialism and postcolonialism), as well as for holding together shifting modes of colonial domination across time. In the context of Australia, we deploy the notion of coloniality to think through both the particularities and commonalities of diverse forms of racialised and oppressive power enacted by the state, including frontier and settler colonialism (on the Australian continent), colonial rule (of the territories of Papua and New Guinea), and hierarchical and paternalistic engagements with other Pacific states, including through ideas and practices of 'development'.

In considering Indigenous Australian and Pacific Islander experiences of labour mobility in relation to one another and longitudinally, this book generates new insights into the nature of that coloniality, as well as into the material, imaginative and affective responses of those who labour on, and through, country. In bringing together Pacific and Indigenous Australian experiences, the book also seeks to push against the disciplinary and epistemological structures that have, with notable exceptions, ${ }^{12}$ delineated these from one another as the subjects of the largely separate fields of Aboriginal/Indigenous studies and Pacific studies. In doing so, it builds on and extends a growing body of historical scholarship that has emphasised trans-local Indigenous networks and political activity. ${ }^{13}$ A particular focus on Australian coloniality and labour mobility experiences within Australia is also intended as a response to the large existing literature on Pacific Islander labour mobility to, and within, New Zealand. ${ }^{14}$

The incursions of the Australian state and capital into Aboriginal and Torres Strait Islander lands and waters, as well as into the wider Pacific region, were (and remain) interconnected exercises of coloniality. The nineteenth-century exploitation of Islanders' labour through the Pacific labour trade was predicated on the dispossession of Aboriginal people in Queensland, and the colonial forms of violence nurtured on the frontier - often wrapped up in discourses of 'larrikinism' and tough settler identity - were the foundation for the material and discursive violence enacted against Islanders. ${ }^{15}$ While distinctions between different forms of

12 Banivanua Mar, Decolonisation and the Pacific.

13 Carey and Lydon, Indigenous Networks; De Costa, A Higher Authority.

14 For example: Hammond and Connell, 'The New Blackbirds?'; Loomis, Pacific Migrant Labour, Class and Racism; Grainger, 'From Immigrant to Overstayer'; Macpherson, Spoonley and Anae, Tangata o te Moana Nui; Teaiwa and Mallon, 'Ambivalent Kinships?'.

15 Banivanua Mar, Violence and Colonial Dialogue. 
coloniality are analytically useful—and, indeed, we sometimes distinguish within this collection between settler colonialism, the direct colonial administration of Papua and New Guinea, and other forms of colonial intervention within the Pacific - it is also the case that both throughout Australia, and throughout the region, the violence of colonialism has been enacted through multiple, changing and often interconnected modalities. For instance, as Ann Curthoys and Clive Moore have argued, the use of Torres Strait Islander labour from the latter half of the nineteenth century can be seen as much an extension of Pacific colonialism as of Queensland colonial labour relations. ${ }^{16}$ Particularly in the pearling and bêche-de-mer industries, Torres Strait Islander labour was used alongside Pacific Islander and Asian labour. Across colonial Queensland and the Torres Strait, racism towards Aboriginal, Chinese and Melanesian people was both cotemporaneous and co-produced. ${ }^{17}$ Colonial settlers themselves were frequently moving back and forth throughout the wider region from 1788 into the nineteenth century in a cycle of 'constant intercolonial movements'. ${ }^{18}$ When the Pacific labour trade and indenture system were concluded at the end of the nineteenth century, Archibald Meston forecast self-sustaining missions on reserves to provide enough Aboriginal workers to replace the Pacific Islanders facing deportation. ${ }^{19}$ These interconnected and mutually productive expressions of coloniality are explored powerfully in Tracey Banivanua Mar's chapter in this volume, which examines the 'inseparable bind' between land and labour in the colonial project of Benjamin Boyd, a white pastoralist who arrived in New South Wales in the mid-nineteenth century. Boyd's use of indentured Pacific labour, Banivanua Mar shows, was bound up in the colonial fantasies of transformation of Aboriginal land into 'productive property'.

Still, while these articulations of coloniality were interconnected, there were important differences in the ways that Aboriginal and Pacific Islander labour were managed. The reserves system that figures like Meston championed, for instance, provided a particular mechanism of control and centralisation from within which Aboriginal people could be pressed into cheap labour. ${ }^{20}$ They also worked to contain those who did not, or would not, work for the colonists, or indeed whose labour was

16 Curthoys and Moore, 'Working for the White People'.

17 Evans, Saunders and Cronin, Race Relations in Colonial Queensland.

18 Curthoys and Moore, 'Working for the White People', 6.

19 Curthoys and Moore, 'Working for the White People'.

20 Evans, 'A Permanent Precedent'. 
undesired. As Patrick Wolfe has argued in his comparative study of race and colonialism, initial attempts by colonists to recruit Indigenous labour were often quickly abandoned:

In principle, it is not good policy to incur reliance on a population that one is simultaneously seeking to eliminate, nor to promote the survival of the bearers of sovereignties that exceed the settler import. ${ }^{21}$

Thus, indentured Pacific labour became a desirable labour force, as its use helped to avoid settler reliance on Aboriginal labour. The use of indenture as a mechanism for facilitating and controlling some Pacific labour has also meant that this labour has historically been easier to track and quantify, allowing the more casual use of Aboriginal labour-often forced, unpaid or paid in rations - to 'slip quietly through the cracks of the historical record'. ${ }^{22}$ This interplay between imported and local labour, and between strategies of confinement and transportation, remind us that labour mobility must also, necessarily, be considered in relation to immobility and constraint, and to both the denial and the refusal of movement. The issue of indenture also raises important distinctions between different groups of Pacific people, with Melanesian labour subject to indenture in a way that Polynesian labour largely was not. One effect of this has been that Māori and other Polynesian labour has, like Aboriginal labour, been far less visible in historical record.

In attending to the intersections of Pacific Islander and Aboriginal and Torres Strait Islander labour mobility, both historical and contemporary, contributors to this volume ask: For what, and whose, ends have Pacific people and Indigenous Australians laboured, both historically and today? Where, and in what ways, do past and present experiences of labour mobility by Pacific and Indigenous Australian peoples resonate, diverge and intersect? What are, or have been, the responses of Indigenous and Pacific peoples to labour mobility, and to the forms of intercultural encounter that labour mobility produces? In exploring these questions, the papers in this collection move between mission history, the mid-nineteenth-century origins of the Pacific labour trade, contemporary fly-in fly-out mining labour, seasonal labour in the horticultural sector and more. Underlying this diversity, strong commonalities of experience

21 Wolfe, Traces of History, 25.

22 Curthoys and Moore, 'Working for the White People', 4. 
emerge, including the role of labour relations in colonialist efforts to produce and discipline particular kinds of Indigenous and Pacific Islander subjects; the ambivalent role of regulation in both ameliorating and reproducing colonial inequalities; and the complex interplay of coercion and agency as Indigenous and Pacific Islander people variously seek out, resist and negotiate experiences of labour mobility.

\section{Producing Indigenous and Pacific Islander Subjects}

Labour is materially, and also symbolically and subjectively, productive. White colonists and the Australian state have attempted to produce Indigenous and Pacific Islander people as particular kinds of subjects to make them exploitable as workers and, conversely, have exploited Indigenous and Pacific Islander workers in their attempts to produce them as particular kinds of subjects. As Banivanua Mar has shown, racialised stereotypes of Melanesians, cast in terms of moral and physical threat and reproduced within literary traditions of savagery and cannibalism, were part of the way that Melanesians were produced through the nineteenth century as 'colonizable, oppressable, and exploitable'. ${ }^{23}$ The shifting codings of Pacific workers that she documents through the nineteenth century — as variously lazy and hard-working, passive and savage, menacing and benign - echo in the racialised, often contradictory, ways in which contemporary Pacific Islanders are depicted in media, political and public discourse, whether in the context of their labour (e.g. through narratives about Islanders as well suited to difficult horticultural work), their perceived failure to labour (e.g. in narratives about welfare dependency) or indeed through the pervasive stereotypes of young Pacific Islanders as delinquent, violent and trouble-making (and thus as unproductive subjects in the making). ${ }^{24}$

While recognising the ambivalence that Wolfe attributes to the use of Indigenous labour by early colonists, labour has nevertheless been similarly implicated in colonial attempts to create and govern Aboriginal and Torres Strait Islander subjects. Labour, as Henry Reynolds documented in With the White People, was valued both economically and as a way of civilising

23 Banivanua Mar, Violence and Colonial Dialogue, 3.

24 Stead, 'Doing "Social Cohesion". 
Aboriginal people. ${ }^{25}$ This civilising project reverberates today through the coercive labour regime installed by the Australian Government in the wake of the 2007 Northern Territory National Emergency Response (the 'Intervention'). As Jon Altman, Melinda Hinkson and others have extensively documented, the Community Development Program (CDP) that was launched in 2014 is profoundly ideological and normative in its character, bound up as it has been in the Intervention's wideranging but acute moral panic about perceived dysfunction in remote Indigenous communities. ${ }^{26}$ As the 200-page report that called for the establishment of the CDP, The Forrest Review: Creating Parity, declared baldly:

Idle hands and a lack of the dignity that work brings have contributed to the dysfunction of many remote communities. Compounding the pernicious effects of welfare, remote Australia is now an easy target for those peddling drugs, illegally sold alcohol and gambling. Full-time Work for the Dole activities from day one of unemployment will keep people active. ${ }^{27}$

Thus justified, the CDP has enacted extensive programs of work, enforced through punitive systems of penalties for noncompliance, that see Indigenous people labouring for an hourly rate of AU\$11, far below the minimum wage. In contrast to Reynolds' observations about Aboriginal labour on colonial frontiers, though, economic value is of little consideration here. Most of the 'jobs' into which Aboriginal people are corralled are unsustainable-'make-work' valued exclusively for its governing and disciplining effects, as Jon Altman elaborates in his chapter in this volume, which takes as its geographical focus the communities around Maningrida in Arnhem Land. ${ }^{28}$ Where the contemporary CDP does echo past labour regimes enacted upon Indigenous peoples is in its devaluing - indeed, its fundamental failure to recognise-other forms of work and labour beyond a particular capitalist, modern ideal. This is a theme that similarly emerges in other chapters. For instance, Shino Konishi documents the failure of the colonial explorer D. W. Carnegie to recognise the Aboriginal labour and forms of economy he encountered through the Gibson and Great Sandy deserts, a myopia that functioned in part to legitimate extreme cruelty towards the Aboriginal people he encountered. Meanwhile, Lucy Davies' insights into the characterisations

25 Reynolds, With the White People.

26 Altman and Hinkson, Culture Crisis.

27 Forrest, 'The Forrest Review', 197.

28 See also Altman, 'Modern Slavery in Remote Australia?'. 
of Papuan and New Guinean female domestics as 'companions' rather than workers demonstrates that this selective privileging of particular conceptions of work and labour at the expense of others is similarly a feature of Australia's colonial engagements with Pacific lives and livelihoods, both within Australia and throughout the region. ${ }^{29}$

Other chapters provide different angles on the articulations of labour and colonial discipline. Scott Mackay and Daniel Guinness chart the experiences of young itaukei (indigenous) Fijians who travel to Australia under the promise of pathways into lucrative jobs within professional rugby, but instead find themselves exploited within low-paying manual jobs. Their labour experiences are rooted in the ethnicised divisions of labour that have characterised coloniality in both Fiji and Australia, and that frame the conditions of possibility for itaukei men. They are also, Mackay and Guinness show, reflective of contemporary neoliberal precepts that hold individual migrant workers responsible for negotiating the conditions of their employment. This logic holds those who do not secure lucrative professional sporting careers (which is to say, the vast majority) responsible for their own fates, and provides the legitimating discourse that sees them compelled instead into positions as cheap labour on the fringes of Australia's labour markets and migration regimes.

The contributions to this volume not only highlight the disciplining aims of various labour relations, but also the particular forms of disciplinary and colonial force enacted (or at least, attempted) through labour mobility. As Sarah Prout Quicke and Fiona Haslam McKenzie note in this volume, the mobility of Indigenous people has often been constructed as a factor in their ungovernability. Yet, both historical and contemporary practices have also sought to encourage or compel mobility as part of explicit attempts to govern and produce 'productive' working subjects. These forms of disciplining include the coerced movements of Indigenous people to settlements, as well as both historical and contemporary demands for Indigenous people to leave remote homes in pursuit of mainstream employment ${ }^{30}$ (and the punishment through CDP labour or the denial of basic services ${ }^{31}$ to those who refuse to leave). Timothy Neale, in this volume, provides a critical genealogy of the idea of 'orbiting', championed by Noel

29 Stead, 'The Price of Fish'; Stead, Becoming Landowners.

30 Konishi and Lui-Chivizhe, 'Working for the Railways'.

31 Helen Davidson, 'WA Plan to Close 100 Remote and Indigenous Communities "Devastating". The Guardian, 18 November 2014. www.theguardian.com/australia-news/2014/nov/18/wa-plan-toclose-100-remote-and-indigenous-communities-devastating. 
Pearson as a model through which remote-living Indigenous people could (and should) move back and forth between culturally significant home communities and urban economies. Neale's observation, that orbiting bolsters the ideological privileging of the life of the migrant worker as the best 'lifestyle choice' for contemporary Indigenous people, is paralleled in key ways by the developmentalism championed by proponents of the SWP, interrogated by Victoria Stead in her exploration of Ni-Vanuatu temporary workers in north-central Victoria.

\section{Regulation and Colonial Inequalities}

A second thematic concern that runs through the chapters gathered here is the ambiguous role of regulation in both ameliorating and prescribing colonial exploitation and hierarchy in the context of labour mobility. As Shino Konishi shows in her account of Aboriginal people kidnapped and subject to gross mistreatment by the explorer Carnegie, the lack of legislative protections for Aboriginal and Torres Strait Islander people in the period of colonial settlement enabled highly exploitative labour relations. Further, as Sarah Prout Quicke and Fiona Haslam McKenzie observe in relation to contemporary fly-in fly-out (FIFO) labour, the fact that contemporary Indigenous workers are entitled to the same legislative protections as non-Indigenous workers has markedly reduced many vulnerabilities. Indeed, they note that Indigenous FIFO labour is, in many ways, facilitated by new kinds of legislative and regulatory frameworks, including those that require mining companies to foster Indigenous employment opportunities as part of their obligations within the context of native title. Nevertheless, the pervasive representational politics associated with the coloniality of power continue to structure Indigenous labour mobilities in ways that produce unique precarities and vulnerabilities.

It is not only the absence of regulation that produces colonial hierarchies and inequalities. As Julia O'Connell Davidson notes in relation to contemporary debt-financed labour migration and the host of mobile and exploitative labour relations that fall under the category of 'modern slavery', legal migration channels can be as likely as illegal ones to lock workers into severely unequal power relationships. ${ }^{32}$ Nor does the legal/

32 Davidson, 'Troubling Freedom'. 
illegal dyad map neatly onto that of protected/vulnerable, she argues; leaving home to work illegally in the informal sector can be a way of increasing personal freedoms for many migrant workers, albeit under risk of detection and deportation. This is the situation for many of the Pacific Islanders whose lives Makiko Nishitani and Helen Lee document in their chapter in this volume. Having initially travelled to Australia on SWP visas, which provide for specific hours and conditions of seasonal labour, some choose to overstay or 'abscond' from their designated places of employment, citing less exploitative and more profitable 'informal' work opportunities, in spite of the challenges and anxieties generated from living and working without documentation. ${ }^{33}$ Historical antecedents to the regulated restraints of contemporary labour mobility schemes emerge in Lucy Davies' sensitive mapping of the experiences of Papuan and New Guinean women who travelled to Australia as servants, nursemaids and domestics for white women. Placing their labour into dialogue with the domestic labour of Aboriginal women, Davies argues that the regulation and government surveillance of these workers, often couched in terms of protections, was a response to the fear caused by the presence of Aboriginal and Pacific Islander women within the private spaces of white homes. In drawing attention to the gendering of colonial power, Davies thus calls attention not only to workers' movements between territories or across large geographical distances, but also to the intimate mobilities of labour across the borders of private and public spheres.

The regulated constraints on rights and belonging, and forms of variegated rights that characterise mobile labour regimes, ${ }^{34}$ compel us to look beyond the kinds of exploitation and vulnerability produced by illegality to what Losurdo describes as the various 'exclusion clauses' that have always accompanied liberal pronouncements of rights and freedoms. ${ }^{35}$ The regulated and racialised hierarchies enacted at the borders of nationstates affect Pacific Islanders entering Australia in ways that do not act upon Indigenous peoples; however, these 'exclusion clauses' nevertheless punctuate the exercise of colonial power against Indigenous lives. These are evident in the kinds of legislated inequalities that characterise the Northern Territory Intervention and the more recent CDP. Indeed, the dark irony of the CDP is that the author of the report that recommended its establishment, Andrew Forrest, is elsewhere lauded as a champion of

33 See also Lan, 'Legal Servitude and Free Illegality'; Mahdavi, Gridlock.

34 Anderson, 'Migration, Immigration Controls'.

35 Losurdo, Liberalism, 342. 
freedom for his role as head of the Walk Free Foundation, an organisation that campaigns against 'modern slavery' in global supply chains. ${ }^{36}$ Coercive labour conditions and exploitative remuneration make the CDP arguably a form of modern slavery. However, instead of being recognised as such, its foundations in intensely racialised, colonial representations of Indigeneity mean that it is legitimised and legally sanctioned.

\section{Coercion and Agency}

Images and discourses of slavery-modern or otherwise-have often ignited debates about the relationship between coercive force and workers' agency. As Victoria Stead argues in her chapter in this volume, these debates have long occupied scholars of the Pacific labour trade, as well as those concerned with contemporary forms of Pacific labour mobility. Discourses of slavery have also, she argues, gained popular traction among contemporary Pacific Islanders. Beyond technical or legalistic debates about the definitional parameters of slavery, the forms of meaning and historical awareness embedded in these discourses urge more nuanced attention to the lived experience of labour, and to the complex interplays of consent and coercion that also animate Tracey Banivanua Mar's chapter on the Islanders 'recruited' to New South Wales by Benjamin Boyd.

In contrast to the Pacific labour trade, the use of Aboriginal labour by Australian colonists began at a time when slavery was still legal in the British Empire. The initial clearances that accompanied colonial settlement were often followed by a subsequent enticement back of Aboriginal people to the fringes of those settlements as a labour force. ${ }^{37}$ 'Aboriginal workers were never slaves in the strict sense', argue Curthoys and Moore, 'but neither were they free'. ${ }^{38}$ In the context of Aboriginal labour in Queensland during the colonial period, Raymond Evans similarly makes a case for the 'striking parallel' between the conditions of slaves and 'unfree' Aboriginal workers, noting that the early colonists perceived Aboriginal workers in terms largely equivalent to those with which they regarded African slaves. ${ }^{39}$ If the Pacific labour trade formally commenced in the aftermath of slavery's abolition, the racialised discourses, images and tropes that sustained this

36 Altman, 'Modern Slavery in Remote Australia?'

37 Curthoys and Moore, 'Working for the White People'.

38 Curthoys and Moore, 'Working for the White People', 4.

39 Evans, “"Kings” in Brass Crescents', 203. 
perception of Aboriginal workers were nevertheless strongly paralleled by those that also sustained the exploitation of Pacific workers. As Banivanua Mar has shown, this exploitation was bolstered by narratives of white settler larrikinism, the 'siege mentality' of tropical settler colonialism and legitimising tropes of the 'the infectiousness of savagery' ${ }^{40}$ In the case of both Pacific Islander and Indigenous people, the substantive and experiential resonances of their historical labour conditions with slavery are articulated within contemporary self-understandings; further, they are affirmed by the kinds of labour that many continue to perform and the material and cultural conditions within which they work. ${ }^{41}$

Nevertheless, neither Indigenous nor Pacific Islander people have ever been simply passive recipients of colonial action. As Reynolds demonstrated close to 40 years ago, and as others have similarly shown, Aboriginal and Torres Strait Islander people were active agents in relationships with white settlers. White colonists undoubtedly did enact violence, force and punitive measures in the exploration and settlement of Australia. There were limits, though, to how much labour could be coerced. Many Aboriginal people in the period up until World War I worked intermittently, combining casual work with traditional food gathering, hunting and livelihood activities — an agentive combining of modern and traditional economies and ways of life that precedes and, in many ways, parallels the 'hybrid economies' that Altman describes in contemporary northern Australia. ${ }^{42}$ Many Aboriginal and Torres Strait Islander people enacted agency in their roles as guides and intermediaries in the process of exploration, ${ }^{43}$ as did Pacific Islanders who voluntarily recruited for periods of indentured labour, some choosing to sign on again when their initial periods of indenture were concluded. ${ }^{44}$ Many Indigenous people continued to understand travel within their own epistemological frameworks, even if it was also shaped by colonialism, a point made by the contributors to Rachel Standfield's edited collection Indigenous Mobilities: Across and Beyond the Antipodes. ${ }^{45}$ In their chapter in this volume, Standfield and Michael J. Stevens likewise draw attention

40 Banivanua Mar, Violence and Colonial Dialogue, 9, 37.

41 Curthoys and Moore, 'Working for the White People'; see also Stead, this volume.

42 Reynolds, With the White People; Altman, 'What Future for Remote Indigenous Australia?.'

43 Konishi, Nugent and Shellam, Indigenous Intermediaries; Shellam, Nugent, Konishi and Cadzow, Brokers and Boundaries.

44 Moore, Kanaka; Scarr, 'Recruits and Recruiters'; Shlomowitz, 'Markets for Indentured'; Shlomowitz, 'Time Expired Melanesian Labor in Queensland'.

45 Standfield, Indigenous Mobilities. 
to the rich worldviews, social structures and epistemologies of movement that have long animated the travels of Kāi Tahu Māori, including to Australia. Kāi Tahu mobility, they argue, was and remains deeply informed by these cultures of movement, even as it has also involved forms of strategic response to historical circumstances and conditions of power and racialised inequality. Ruth (Lute) Faleolo similarly foregrounds Pasifika cultures and patterns of meaning in her exploration of the labour migration experiences of contemporary Tongan and Samoan trans-Tasman migrants. Highlighting holistic Pasifika concepts of 'a good and happy life' ${ }^{46}$ - mo ui 'oku lelei in Tongan and ola manuia in Samoan-Faleolo maps the complex ways in which Pacific labour migrants negotiate both the possibilities for betterment, and forms of racialised and regulatory obstacles, that their migrations entail.

Faleolo's attention to Pasifika migrating to Australia from New Zealand also highlights the particular place and role of New Zealand in Pacific Islanders' labour mobility experiences, including as a triangulating node in circuits that connect New Zealand, Australia and the Pacific Islands. For many of Faleolo's informants, as for the Kāi Tahu Māori who Standfield and Stevens discuss, the special migration relationship between New Zealand and Australia offers some reprieve from the regulatory regimes otherwise enacted at the border for Pacific Islanders seeking access to Australia. Stevens has also, elsewhere, demonstrated the ways in which Kāi Tahu Māori have pursued work within Australian maritime industries, both as an expression of Kāi Tahu lifeways and as an escape from their own dispossession by white settler society in Aotearoa/New Zealand. ${ }^{47}$ Nevertheless, in each case, trans-Tasman migrants encountered other forms of racialised constraint that pushed back against their pursuit of wellbeing, mana (authority) and livelihood.

Rather than fall into unhelpful bifurcations of choice and coercion, freedom and force, the scholars in this volume-and the scholars on whose work this volume builds - insist on the possibility (indeed, the necessity) of recognising creativity, strategic decision-making and political resistance in ways that do not minimise the sharp edges of colonial power against which such expressions of agency were, and are, enacted. ${ }^{48}$

46 Faleolo, 'Pasifika Trans-Tasman Migrant Perspectives'.

47 Stevens, 'Māori History as Maritime History'.

48 Banivanua Mar, Decolonisation and the Pacific; Konishi, Nugent and Shellam, Indigenous Intermediaries; Carey and Lydon, Indigenous Networks; De Costa, A Higher Authority; Standfield, Indigenous Mobilities. 
As Tracey Banivanua Mar puts it in her chapter in this volume, writing about the Ni-Vanuatu men and boys who found themselves transported to the colony of New South Wales in 1847: 'As active agents within a new world of differentially racialised opportunity and constraint, they created "labour lines", interweaving fates and creating entangled relationships of contingency that manifested new Oceanias.'

\section{Outline of the Book}

The interplay of force and agency emerges strongly in Chapter 2, Shino Konishi's 'Intermediaries, Servants and Captives: Disentangling Indigenous Labour in D. W. Carnegie's Exploration of Australia'. The history and contribution of Aboriginal guides to the exploration of Australia has long been recognised and even celebrated, Konishi observes, from the gifting of king plates to the erecting of memorials. Yet, the labour that Aboriginal people provided was more diverse than the iconic imagery of guides such as Wylie leading a lone explorer suggests. Approaching the colonial exploration of the Australian continent and its waters as a 'mobile enterprise', Konishi charts the 1896 expedition of D. W. Carnegie through the Gibson and Great Sandy deserts, drawing attention to the imaginings of both the explorers and Indigenous people involved. The use of colonised labour, she argues, was 'riddled with contradictions', both desired and derided. Konishi shows that Aboriginal labour and economy were not recognised by Carnegie and his men as work, with offers of reciprocal exchange and trade by some of those that they encountered in their exploration rejected in favour of more ruthless and coercive tactics, including the kidnapping of Aboriginal people to act as guides or to find water. Rather than see this behaviour as the result of desperation on the part of the colonial explorers (unfortunate but perhaps understandable actions by parched men in an inhospitable terrain), Konishi insists that we recognise it as flowing from particular forms of practice and understanding within which the patriarchal control of indentured and Aboriginal labour was part of the formation of settler masculinity.

In Chapter 3, Tracey Banivanua Mar attends to the intersections of coloniality in the Pacific and the dynamics of settler colonialism that Konishi's chapter articulates. In "Boyd's Blacks": Labour and the Making of Settler Lands in Australia and the Pacific', Banivanua Mar explores the experiences and political agency of $\mathrm{Ni}$-Vanuatu men and boys 
'recruited' to New South Wales by the pastoralist Benjamin Boyd in 1847. Her analysis, and the history of Australian pastoralism, urge attention to the interconnections of land, labour and commerce within the settler colony and the wider region. Boyd's importation of Pacific Islander labour to work on his pastoral empire is generally remembered, if it is remembered at all, as a failed precursor to the Pacific labour trade that commenced two decades later. Reading through the gaps and biases of the colonial archives, Banivanua Mar attempts to reassemble the lived experiences of $\mathrm{Ni}$-Vanuatu men and boys, including a group who absconded shortly after their arrival on Boyd's Riverina station and marched towards the port cities of Sydney and Melbourne. In doing so, she explores what their experiences tell us about the lines of labour that connected colonists across Australia and the Pacific Islands, suggesting that their stories demand a reconfiguration of the way we have come to understand the history of this relationship and, in particular, the scale and spectrum on which we have historically understood the Australian indentured labour trade.

The gendered dimensions of labour mobility, touched on in Konishi's discussion of settler masculinity, emerge again in Chapter 4 with Lucy Davies' examination of Papuan and New Guinean female domestic workers travelling to Australia in the mid-twentieth century. Arguing for the inclusion of Papuan and New Guinean servants within the broader historiography of Indigenous domestic labour, Davies maps the ambivalent effects of both regulation and affect. Not unlike Pacific Islanders involved in the early years of the Pacific labour trade, Papuan and New Guinean domestics travelled to Australia as indentured workers, were monitored closely during their time in the country and were expelled at the conclusion of their contracts. Regulatory processes associated with these labour migrations involved little consultation with the women themselves or with applications submitted by their employers, and few avenues were afforded them to exercise autonomy, express dissent and improve their working lives. Colonial descriptions of domestic servants as 'companions', of their wages as 'pocket money' and of their white employers as being akin to 'family', speak to particularly gendered ways through which Pacific women's labours were diminished and controlled, and to the ambiguous entwining of intimacy and colonial power.

In Chapter 5, 'New Histories but Old Patterns: Kāi Tahu in Australia', Rachel Standfield and Michael J. Stevens turn their attention to the relationships between historical and contemporary patterns of migration by Kāi Tahu Māori from Te Waipounamu on New Zealand's South Island. 
Māori travel to the Australian continent began early in its European invasion, and has played an important role in migration to Australia throughout its colonial history, including a dramatic increase since the 1960s. Standfield and Stevens, who is Kāi Tahu, focus on the initial travel of Kāi Tahu people to Australia during the early to mid-nineteenth century to explore the ways that travel reflects Kāi Tahu worldviews, social structures and economic priorities. Asserting the centrality of mobility as foundational to Kāi Tahu identity_and also as something reconfigured through the experience of settler colonialism—they show how Kāi Tahu rakatira (chiefs) used mobility, the labour of their communities, and iwi (tribal) resources and trade goods to shape tribal wealth and bolster mana. This consolidated the Käi Tahu position in terms of other tribal communities and influenced trade and other negotiations with the nascent state in early colonial New Zealand. Arguing for a whakapapa (genealogy)-based methodology, Standfield and Stevens seek to produce histories that speak to the concerns and desires of contemporary Käi Tahu people, many of whom regularly visit or live permanently in Australia.

Shifts and continuities between past and present labour migrations remain a theme in Victoria Stead's chapter, 'Money Trees, Development Dreams and Colonial Legacies in Pasifika Horticultural Labour'. Stead considers the experiences of a group of $\mathrm{Ni}$-Vanuatu workers employed through the Seasonal Worker Programme in the Shepparton horticultural industry, locating these in relation to the nineteenth-century 'blackbirding' of $\mathrm{Ni}$-Vanuatu workers to the sugar plantations of north-eastern Australia, to consider the historical trajectories and complex ecologies of Australian coloniality in relation to the Pacific. Discourses about contemporary Pacific Islander seasonal labour in the horticultural industry frequently invoke a language of 'slavery', making direct connections to the exploitative, racialised and hierarchical labour relations that characterised the Pacific labour trade. At the same time, SWP labour is also actively and enthusiastically sought out by many Pacific workers, including as a pathway to 'development'. Mapping the messy convergences of development dreams and colonial legacies in the horticultural landscapes of north-central Victoria, Stead challenges the bifurcations of 'slavery' and 'freedom' within liberal thought as well as within much academic and popular commentary on Pacific Islander labour. This chapter suggests instead that we attend to the ambivalences of Pacific labour experiences, locating these in the context of long-running, known and felt histories of racialised inequalities. 
A little further north-west from Shepparton, in Mildura and Robinvale, Makiko Nishitani and Helen Lee also examine the experiences of Pacific horticultural workers in Chapter 7, "Becoming "Overstayers": The Coloniality of Citizenship and the Resilience of Pacific Farm Workers'. Nishitani and Lee's focus is on Pacific irregular migrants who work, often over many years, without work permits. The migrations of Pacific Islanders to rural Australia to work as seasonal labourers began in the 1980s, often motivated by the relative lack of surveillance of the industry. ${ }^{49}$ Pacific irregular migrants include those who overstay their visas, work while on visitor visas that formally prohibit employment and abscond from the SWP. Examining the perspectives and experiences of Pacific irregular migrants themselves, both past and present, and the government's shifting responses to illegal workers, they draw attention to the ways in which different categorisations and conditions of legality and illegality are constructed. In spite of increases in surveillance and enforcement, many of Nishitani and Lee's informants continue to assess participation in the legalised SWP as posing greater risks of exploitation than the prospect of overstaying their visas and working irregularly.

In Chapter 8, Ruth (Lute) Faleolo focuses on the particular experience of Pasifika peoples migrating from New Zealand to Brisbane, Australia, in 'Wellbeing Perspectives, Conceptualisations of Work and Labour Mobility Experiences of Pasifika Trans-Tasman Migrants in Brisbane'. Drawing on interviews with Samoan and Tongan Pasifika and, as with Standfield and Steven's chapter, utilising indigenous methodology in her research, Faleolo highlights the significance of holistic Pasifika concepts of wellbeing-the Tongan concept of mo ui 'oku lelei and the Samoan concept of ola manuia, translated as 'a good and happy life'-in motivating and informing the experience of trans-Tasman migrants. In contrast to the paternalistic developmentalism evident in the SWP, which are also evident in Konishi's considerations of colonial labour relations, Faleolo posits indigenous Pasifika developmentalist discourses within which labour mobility is an opportunity for progressive betterment, reflected in the importance accorded to achieving home ownership. Faleolo offers a gentle pushback against the notion of 'labour mobility', instead positing labour as one aspect of a multidimensional conceptualisation of mobility and its promises.

49 Nishitani and Lee, 'Invisible Islanders?'. 
Urban Pasifika experiences of labour mobility are also the focus of Scott Mackay and Daniel Guinness's contribution, 'Coloniality of Power and the Contours of Contemporary Sport Industries: Fijians in Australian Rugby'. In contrast to many forms of Pacific labour mobility, which are oriented towards low-paying, so-called 'unskilled' labour, professional rugby offers the promise (if rarely the reality) of life-changing wealth and prestige. Individual and collective mobility aspirations, Mackay and Guinness argue, are intertwined with understandings and histories of what it is to be Fijian in a postcolonial nation and global world, and are highly influenced by gender and ethnicity. Mapping the 'economies of hope' that motivate young itaukei (indigenous Fijian) men to travel to Australia in pursuit of rugby dreams, Mackay and Guinness also chart the disappointments of those who do not secure professional contracts but rather find themselves confined to the margins of the Australian labour market, working as seasonal workers, manual labourers or religious workers as they also play for amateur or semi-professional rugby clubs. Their experiences highlight the intertwining of Australian and Fijian migration regimes, labour markets and social worlds, exposing the labour lines that must be traversed, and the contours of the global and domestic labour markets and economies of hope.

Chapter 10 takes us back to Australian Indigenous experiences, with Sarah Prout Quicke and Fiona Haslam McKenzie's study of Indigenous engagement in the resources sector through FIFO employment arrangements with a global mining firm. As with professional rugby contracts, FIFO labour promises big incomes. It is a form of labour mobility very much reflective of contemporary global neoliberal and neo-colonial market systems, although in other respects FIFO labour experiences are consistent with longer-running trends. In centring the localised experiences of Indigenous peoples in their narrative, Prout Quicke and Haslam McKenzie illuminate the scaled effects on Indigenous mobilities and lifeworlds of articulation into the operational spheres of transnational institutions. Key themes emergent in their discussion include the performance and transformation of kinship structures and customary economic practices in the context of market-based labour mobility. In this highly regulated, highly paid and highly formalised work environment, Indigenous workers negotiate complex calculations of benefits and cost, including long shifts in male-dominated, remote and arid environments, regular cycles of separation and reunion with family, disruptions to rhythms and routines, increased demands related to increased salary, and new forms of volatility and precarity. 
In Chapter 11, Timothy Neale likewise attends to contemporary, neoliberal imaginings of labour mobility in 'Mysterious Motions: A Genealogy of "Orbiting" in Australian Indigenous Affairs'. Advocated by the Indigenous public intellectual Noel Pearson, the notion of 'orbiting' envisions circuits of movement through which remote-living Indigenous people could and should 'orbit' between urban 'real job' markets and their remote homes. ${ }^{50}$ Neale argues that the origins, logics and effects of orbiting, which has been described as enabling the 'best of both worlds' for Indigenous people and has been positively received by policymakers, nevertheless remains mysterious. Locating the concept in relation to more critical analyses of diaspora and exile that have emerged in post-2000s Indigenous Australia, ${ }^{51}$ Neale presents a genealogy of orbiting that tracks the shifting imaginaries of work, labour and governance informing Indigenous policy prior to, and now beyond, the ostensible end of self-determination.

Finally, in Chapter 12, Jon Altman extends the concern with new forms of Indigenous mobility considered by Neale, Prout Quicke and Haslam McKenzie, and in the contexts of Pacific workers by Stead, and Nishitani and Lee, in turning his attention to the forms of 'bureaucratic violence' enacted against those Indigenous people who resist neoliberal calls to move for employment. In 'Of Pizza Ovens in Arnhem Land: The State Quest to Restructure Aboriginal Labour in Remotest Australia, Altman focuses on those Indigenous Australians who have regained title to their ancestral lands. Subsequently, they wish to live at homelands and secure a livelihood that re-engages with pre-colonial forms that are fundamentally at odds with absent mainstream employment. Using his long-term field work at Mumeka in west Arnhem Land as an exemplar, he illustrates how, in the recent past, truly bizarre forms of enterprise, like pizza ovens, chicken coops and market gardens, have been underwritten by the recolonising state and a coopted regional Indigenous organisation to implement regimes to govern and produce acceptable Indigenous subjects. He highlights the emergence of the Australian Government's $\mathrm{CDP}$ as a form of bureaucratic violence that is predicated on an imagined incorporation of Indigenous labour into forms of capitalist enterprise that have never emerged in west Arnhem Land since colonisation 60 years ago. Altman's analysis points to labour regimes of coercion and punishment, regimes that are of the contemporary moment, but which

50 See also Neale, Wild Articulations.

51 Burke, 'Indigenous Diaspora'; Hinkson, 'Precarious Placemaking'. 
resonate in powerful ways with the histories mapped through previous chapters. This concluding chapter bookends Konishi's opening, which argues that Aboriginal labour and economy were not recognised by nineteenth-century explorers like Carnegie as work. Altman laments the contemporary situation that replicates such myopia and that has seen the destruction of emerging and productive forms of plural economy. State projects promise capitalist improvement and the closing of employment gaps, but tragically fail to deliver anything for most staying at home except growing impoverishment and enhanced welfare dependence.

The interdisciplinarity reflected in this bookending, and throughout the volume, is highlighted in Lynette Russell's Afterword. 'Good and meaningful' history, she reminds us, requires such interdisciplinarity. Situating this project in the context of a transforming university sector as well as in relation to its scholarly antecedents, Russell's comments reiterate the value of comparative and collective inquiry, highlighting what is possible when an exchange among scholars becomes 'more than the sum of its parts'.

\section{Bibliography}

Altman, Jon. 'Modern Slavery in Remote Australia?'. Arena Magazine, no. 150 (Oct 2017): 12-15.

' What Future for Remote Indigenous Australia? Economic Hybridity and the Neoliberal Turn'. In Culture Crisis: Anthropology and Politics in Aboriginal Australia, edited by Jon Altman and Melinda Hinkson, 259-80. Sydney: UNSW Press, 2010.

Altman, Jon and Melinda Hinkson, eds. Culture Crisis: Anthropology and Politics in Aboriginal Australia. Sydney: UNSW Press, 2010.

Anderson, Bridget. 'Migration, Immigration Controls and the Fashioning of Precarious Workers'. Work, Employment \& Society 24, no. 2 (2010): 300-17. doi.org/10.1177/0950017010362141.

Banivanua Mar, Tracey. Decolonisation and the Pacific: Indigenous Globalisation and the Ends of Empire. Cambridge: Cambridge University Press, 2016.

Violence and Colonial Dialogue: The Australian-Pacific Indentured Labor Trade. Honolulu: University of Hawai i Press, 2007. 
Burke, Paul. 'Indigenous Diaspora and the Prospects for Cosmopolitan "Orbiting": The Warlpiri Case'. The Asia Pacific Journal of Anthropology 14, no. 4 (2013): 304-22. doi.org/10.1080/14442213.2013.804870.

Carey, Jane and Jane Lydon, eds. Indigenous Networks: Mobility, Connections and Exchange. London: Routledge, 2014. doi.org/10.4324/9781315766065.

Curthoys, Ann and Clive Moore. 'Working for the White People: An Historiographic Essay on Aboriginal and Torres Strait Islander Labour'. Labour History 69 (1995): 1-29. doi.org/10.2307/27516388.

Davidson, Julia O'Connell. 'Troubling Freedom: Migration, Debt, and Modern Slavery'. Migration Studies 1, no. 2 (2013): 176-95. doi.org/10.1093/ migration/mns002.

De Costa, Ravindra Noel John. A Higher Authority: Indigenous Transnationalism and Australia. Sydney: UNSW Press, 2006.

Evans, Raymond. “"Kings” in Brass Crescents: Defining Aboriginal Labour Patterns in Colonial Queensland'. In Indentured Labour in the British Empire, 1834-1920, edited by Kay Saunders, 183-212. London: Croom Helm, 1984.

-. 'A Permanent Precedent': Dispossession, Social Control and the Fraser Island Reserve and Mission, 1897-1904. St Lucia: University of Queensland Aboriginal and Torres Strait Islanders Unit, 1991.

Evans, Raymond, Kay Saunders and Kathryn Cronin. Race Relations in Colonial Queensland: A History of Exclusion, Exploitation and Extermination. St Lucia: University of Queensland Press, 1988.

Faleolo, Ruth (Lute). 'Pasifika Trans-Tasman Migrant Perspectives of Well-Being in Australia and New Zealand'. Pacific Asia Inquiry 7, no. 1 (2016): 63-74.

Fijn, Natasha, Ian Keen, Christopher Lloyd and Michael Pickering, eds. Indigenous Participation in Australian Economies II: Historical Engagements and Current Enterprises. Canberra: ANU E Press, 2012. doi.org/10.22459/ IPAE.07.2012.

Forrest, Andrew. 'The Forrest Review: Creating Parity'. Canberra: Commonwealth of Australia, 2014.

Grainger, Andrew. 'From Immigrant to Overstayer: Samoan Identity, Rugby, and Cultural Politics of Race and Nation in Aotearoa/New Zealand'. Journal of Sport and Social Issues 30, no. 1 (2006): 45-61. doi.org/10.1177/ 0193723505284277. 
Hammond, Jeremy, and John Connell. 'The New Blackbirds? Vanuatu Guestworkers in New Zealand'. New Zealand Geographer 65, no. 3 (2009): 201-10. doi.org/10.1111/j.1745-7939.2009.01163.x.

Hau'ofa, Epeli. 'Our Sea of Islands'. The Contemporary Pacific 6, no. 1 (2004): 147-61.

Hinkson, Melinda. 'Precarious Placemaking'. Annual Review of Anthropology 46 (2017): 49-64. doi.org/10.1146/annurev-anthro-102116-041624.

Konishi, Shino. 'Idle Men: the Eighteenth-Century Roots of the Indigenous Indolence Myth'. In Passionate Histories: Myth, Memory \& Indigenous Australia, edited by Frances Peters-Little, Ann Curthoys and John Docker, 99-122. Canberra: ANU E Press, 2010. doi.org/10.22459/PH.09.2010.05.

Konishi, Shino and Leah Lui-Chivizhe. 'Working for the Railways: Torres Strait Islander Labour and Mobility in the 1960s'. Journal of Australian Studies 38, no. 4 (2014): 445-56. doi.org/10.1080/14443058.2014.952766.

Konishi, Shino, Maria Nugent and Tiffany Shellam, eds. Indigenous Intermediaries: New Perspectives on Exploration Archives. Canberra: ANU Press and Aboriginal History, 2015. doi.org/10.22459/II.09.2015.

Lan, Pei-Cha. 'Legal Servitude and Free Illegality: Migrant "Guest Workers" in Taiwan'. In Asian Diasporas: New Conceptions, New Frameworks, edited by Rhacel S. Parreńas and Lok C. D. Siu, 253-77. Stanford: Stanford University Press, 2007.

Loomis, Terrence. Pacific Migrant Labour, Class and Racism in New Zealand: Fresh off the Boat. Aldershot: Avebury, 1990.

Losurdo, Domenico. Liberalism: A Counter-History. London: Verso, 2011.

MacDermott, Therese and Brian Opeskin. 'Regulating Pacific Seasonal Labour in Australia'. Pacific Affairs 83, no. 2 (2010): 283-305. doi.org/10.5509/ 2010832283.

Maclellan, Nic and Peter Mares. 'Remittances and Labour Mobility in the Pacific: A Working Paper on Seasonal Work Programs in Australia for Pacific Islanders'. Working Paper, Institute for Social Research, Swinburne University of Technology, 2006.

Macpherson, Cluny, Paul Spoonley and Melani Anae, eds. Tangata o te Moana Nui: The Evolving Identities of Pacific Peoples in Aotearoa/New Zealand. Palmerston North: Dunmore Press, 2001. 
Mahdavi, Pardis. Gridlock: Labor, Migration and Human Trafficking in Dubai. Stanford: Stanford University Press, 2011.

Mares, Peter and Nic Maclellan. 'Pacific Seasonal Workers for Australian Horticulture: A Neat Fit?'. Asian and Pacific Migration Journal 16, no. 2 (2007): 271-88. doi.org/10.1177/011719680701600207.

Martínez, Julia and Adrian Vickers. The Pearl Frontier: Indonesian Labour and Indigenous Encounters in Australia's Northern Trading Network. Honolulu: University of Hawai'i Press, 2015. doi.org/10.21313/hawaii/9780824840020. 001.0001 .

Mignolo, Walter D. and Arturo Escobar, eds. Globalization and the Decolonial Option. Oxon: Routledge, 2010.

Moore, Clive. Kanaka: A History of Melanesian Mackay. Port Moresby: University of Papua New Guinea Press, 1985.

Neale, Timothy. Wild Articulations: Environmentalism and Indigeneity in Northern Australia. Honolulu: University of Hawai'i Press, 2017. doi.org/10.21313/ hawaii/9780824873110.001.0001.

Nishitani, Makiko and Helen Lee. 'Invisible Islanders? Precarious Work and Pacific Islander Settlers in Rural Australia'. Pacific Studies 40, no. 3 (2017): 430-49.

Pearson, Noel. 'The Cape York Partnership Plan'. Brisbane: The Brisbane Institute, 2000.

—. 'Radical Hope: Education and Equality in Australia'. Quarterly Essay 35 (2009).

—. Up from the Mission: Selected Writings. Melbourne: Black Inc., 2011.

Quijano, Aníbal. 'Coloniality and Modernity/Rationality'. Cultural Studies 21, no. 2-3 (2007): 168-78. doi.org/10.1080/09502380601164353.

- 'Coloniality of Power, Ethnocentrism, and Latin America'. Nepantla 1, no. 3 (2000): 533-80.

Reynolds, Henry. With the White People: The Crucial Role of Aborigines in the Exploration and Development of Australia. Ringwood: Penguin, 1990.

Scarr, Deryck. 'Recruits and Recruiters: A Portrait of the Pacific Islands Labour Trade'. The Journal of Pacific History 2, no. 1 (1967): 5-24. doi.org/10.1080/ 00223346708572099. 
Sharp, Ian and Colin Tatz, eds. Aborigines in the Economy. Brisbane: Jacaranda Press, 1966.

Shellam, Tiffany, Maria Nugent, Shino Konishi and Allison Cadzow, eds. Brokers and Boundaries: Colonial Exploration in Indigenous Territory. Canberra: ANU Press and Aboriginal History, 2016. doi.org/10.22459/BB.04.2016.

Shlomowitz, Ralph. 'Markets for Indentured and Time-Expired Melanesian Labour in Queensland, 1863-1906: An Economic Analysis'. The Journal of Pacific History 16, no. 2 (1981): 70-91. doi.org/10.1080/00223348108572416.

—_. 'Time-Expired Melanesian Labor in Queensland: An Investigation of Job Turnover, 1884-1906'. Pacific Studies 8, no. 2 (1985): 25-44.

Standfield, Rachel, ed. Indigenous Mobilities: Across and Beyond the Antipodes. Canberra: ANU Press and Aboriginal History, 2018. doi.org/10.22459/ IM.06.2018.

Stead, Victoria. Becoming Landowners: Entanglements of Custom and Modernity in Papua New Guinea and Timor-Leste Honolulu: University of Hawai'i Press, 2017.

—_. 'Doing "Social Cohesion": Cultural Policy and Practice in Outer Metropolitan Melbourne'. Critical Social Policy 37, no. 3 (2017): 405-24. doi.org/10.1177/0261018316681283.

—. 'Mobility and Emplacement in North Coast Papua New Guinea: Worlding the Pacific Marine Industrial Zone'. The Australian Journal of Anthropology 27, no. 1 (2016): 30-48. doi.org/10.1111/taja.12174.

— . 'The Price of Fish: Problematising Discourses of Prosperity at the Pacific Marine Industrial Zone'. In Securing a Prosperous Future: Papers from the Second Annual Alfred Deakin Research Institute Papua New Guinea Symposium, 2012, edited by Jonathan Ritchie and Michelle Verso, 197-230. Goolwa: Crawford House Publishing, 2014.

Stevens, Michael J., 'Māori History as Maritime History: A View from The Bluff. In New Zealand and the Sea: Historical Perspectives, edited by Frances Steel, 156-80. Wellington: Bridget Williams Books, 2018. doi.org/10.7810/ 9780947518707_8.

Taylor, John and Martin Bell, eds. Population Mobility and Indigenous Peoples in Australasia and North America. London: Routledge, 2004. 
Teaiwa, Teresia and Sean Mallon. 'Ambivalent Kinships? Pacific People in New Zealand'. In New Zealand Identities: Departures and Destinations, edited by James H. Liu, Tim McCreanor, Tracey McIntosh and Teresia Teaiwa, 207-29. Wellington: Victoria University Press, 2005.

Wilson, Rob and Christopher Leigh Connery, eds. The Worlding Project: Doing Cultural Studies in the Era of Globalization. Santa Cruz: New Pacific Press, 2007.

Wolfe, Patrick. Traces of History: Elementary Structures of Race. London: Verso, 2016. doi.org/10.1111/1468-229X.12265.

\section{Newspapers}

\section{The Guardian}

Northern Territory News 
This text is taken from Labour Lines and Colonial Power: Indigenous and Pacific Islander Labour Mobility in Australia, edited by Victoria Stead and Jon Altman, published 2019 by ANU Press, The Australian National University, Canberra, Australia.

doi.org/10.22459/LLCP.2019.01 